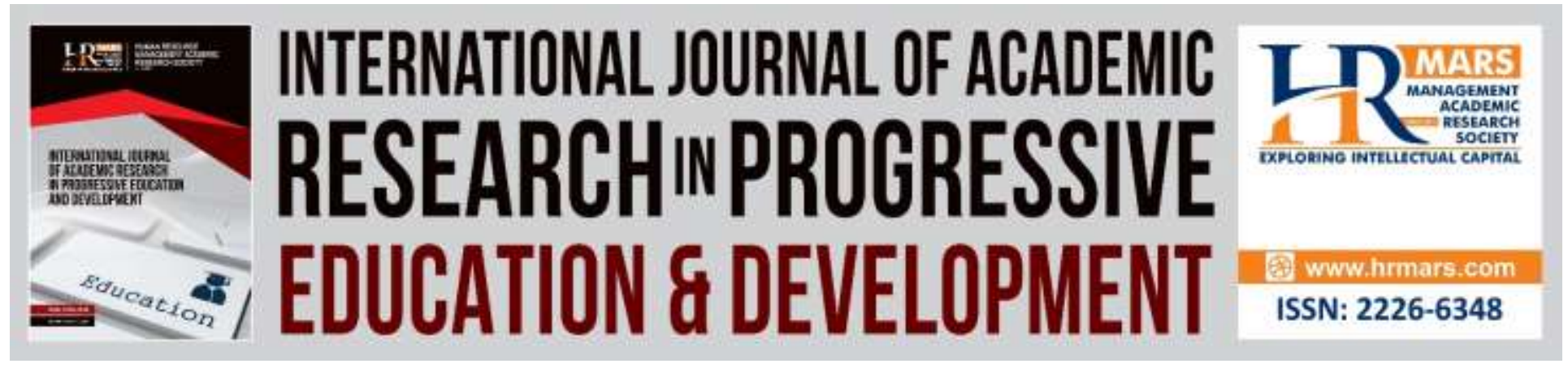

\title{
Linking the Malaysia's Solid Waste Management Policy Instruments with Household Recycling Behavior
}

\author{
Yuzlina Mohd Yusop, Nooraini Othman
}

To Link this Article: http://dx.doi.org/10.6007/IJARPED/v8-i4/6567

DOI:10.6007/IJARPED/v8-i4/6567

Received: 15 October 2019, Revised: 30 October 2019, Accepted: 11 November 2019

Published Online: 28 November 2019

In-Text Citation: (Yusop, Othman, 2019)

To Cite this Article: Yusop, Y. M., Othman, N. (2019). Linking the Malaysia's Solid Waste Management Policy Instruments with Household Recycling Behavior. International Journal of Academic Research in Progressive Education and Development, 8(4), 474-488.

Copyright: (C) 2019 The Author(s)

Published by Human Resource Management Academic Research Society (www.hrmars.com)

This article is published under the Creative Commons Attribution (CC BY 4.0) license. Anyone may reproduce, distribute, translate and create derivative works of this article (for both commercial and non-commercial purposes), subject to full attribution to the original publication and authors. The full terms of this license may be seen at: http://creativecommons.org/licences/by/4.0/legalcode

Vol. 8(4) 2019, Pg. 474 - 488

http://hrmars.com/index.php/pages/detail/IJARPED

JOURNAL HOMEPAGE

Full Terms \& Conditions of access and use can be found at http://hrmars.com/index.php/pages/detail/publication-ethics 


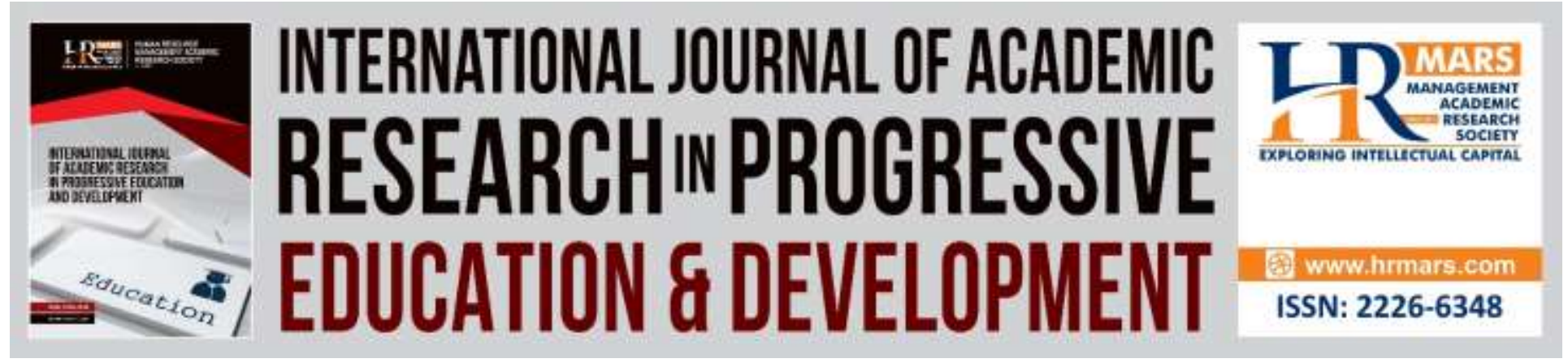

\title{
Linking the Malaysia's Solid Waste Management Policy Instruments with Household Recycling Behavior
}

\author{
Yuzlina Mohd Yusop \\ Perdana Centre of Science, Technology \& Innovation Policy, Razak Faculty of Technology and \\ Informatics, UTM \\ Email: yyusop2000@yahoo.co.uk
}

Nooraini Othman

Perdana Centre of Science, Technology \& Innovation Policy, Razak Faculty of Technology and Informatics, UTM

Email: p-noraini@utm.my

\begin{abstract}
The environmental problems faced by the world population today is the result of human daily activities. One of the contributing sources to the environmental problems is the growth of solid waste. Solid waste generation increases as a result of economic progress, urbanization, population growth and consumer-based lifestyles. The urban areas of Asia is expected to spend at least US\$50 billion per year in 2025 on solid waste management. Malaysia, experiencing rapid economic prosperity, is also faced with challenges in solid waste management. This paper will highlight the present state of waste generation trends, its management, the waste management policies and strategies with specific focus on recycling for the household sector. Recycling has been highlighted for decades as a plausible option for sustainable waste management but still faced with various challenges. This paper will provide a brief classification of the policy instruments adopted in achieving the policy objectives. This provide the basis for future research to analyse the households' perspective on the effectiveness of implemented policy instruments. It is crucial for policymakers to understand the behavioral aspect of the policy instruments in planning future comprehensive strategies.

Keywords: Solid Waste Management, Policy Instruments, Recycling Behavior, Theory of Planned Behavior, Perceived Policy Effectiveness

\section{Background}

The world is urbanizing at unprecedented rate particularly for cities in Asia. Economic progress, population growth, level of affluence have resulted to increase in consumption of
\end{abstract}


goods and services that correspondingly causing increase in waste generation. Globally, the waste generation level is 1.3 billion tonnes per year and is estimated to increase to 2.2 billion tonnes per year by 2025 (The World Bank, 2012). Asia's waste generation level is estimated to double to about 1.8 million tonnes per day by 2025. It is also estimated that the amount spent by the urban areas of Asia will double to at least US\$50 billion per year in 2025 (The World Bank, 1999). The urban populace generate almost three times the amount of waste compared to those living in rural areas. Poorly managed waste will have serious implication to health, environment and the economy.

\section{Solid Waste Scenario in Malaysia}

Solid waste management is one of the major environmental issue in Malaysia as landfilling remain as the main disposal method of which the solid waste generation continues to increase annually (Johari, Alkali, Hashim, Ahmed, \& Mat, 2014; Moh \& Abd. Manaf, 2017). In Malaysia, solid waste is defined as any material including scrap material, unwanted substance or rejected products arising from human activity that are required by the authority to be disposed of, excluding scheduled or harzadous wastes, sewage and radioactive wastes (Government of Malaysia, 2007). Malaysia's solid waste generation comprises $64 \%$ of municipal solid waste (MSW) while the remaining is composed of industrial waste $(25 \%)$, commercial waste $(8 \%)$ and construction waste (3\%) (Moh \& Manaf, 2014).

Household sector is the main source of MSW (Moh \& Manaf, 2017). MSW generation escalated from 21,455 tonnes per day (2000) to 33,000 tonnes per day (2012). Current statistics recorded around 38,000 tonnes of waste is generated per day (Siti Rohana, 2017). The average per capita urban resident generation of solid waste in Malaysia is estimated at about 0.80 $\mathrm{kg} /$ person/day in 2005 which increases to $1.17 \mathrm{~kg}$ per person per day in 2016 (Mentek, 2017). The estimated waste generation is higher in major cities reaching $1.7 \mathrm{~kg}$ per person per day (Jalil, Basri, Ahmad Basri, \& AbuShammala, 2015). Table 1 shows the trend of waste generation by state and federal territories in Peninsular Malaysia. MSW waste composition is dominated by organic waste $(44.5 \%)$ followed by plastic $(13.2 \%)$, diapers $(12.1 \%)$, paper $(8.5 \%)$, garden waste $(5.8 \%)$, glass (3.3\%) and others (12.6\%) (SWCorp Malaysia, 2012). 
INTERNATIONAL JOURNAL OF ACADEMIC RESEARCH IN PROGRESSIVE EDUCATION AND DEVELOPMENT

Vol. 8, No. 4, 2019, E-ISSN: 2226-6348 @ 2019 HRMARS

Table 1: Generation of municipal solid waste by states and federal territories in Peninsular Malaysia (2010 - 2018)

\begin{tabular}{|c|c|c|c|c|c|}
\hline States/Federal & 2010 & 12 & 2014 & $2017^{*}$ & $18^{*}$ \\
\hline \multirow[b]{2}{*}{ Perlis } & \multicolumn{3}{|c|}{ (tonnes/day) } & \multicolumn{2}{|c|}{ tonnes } \\
\hline & 286 & 307 & 163 & 41,894 & 42,208 \\
\hline Kedah & 1,937 & 2,078 & 2,448 & 456,182 & 500,975 \\
\hline WP Kuala Lumpur & 3,698 & 3,968 & 2,525 & 773,684 & 760,174 \\
\hline WP Putrajaya & NA & NA & 159 & 48,633 & 53,272 \\
\hline Negeri Sembilan & 1,107 & 1,188 & 1,281 & 278,697 & 291,383 \\
\hline Melaka & 752 & 807 & 1,030 & 233,548 & 248,210 \\
\hline Johor & 2,800 & 3,005 & 4,206 & 932,494 & 912,907 \\
\hline Pahang & 1,400 & 1,502 & 1,052 & 302,306 & 289,524 \\
\hline Kelantan & 1,512 & 1,623 & 1,933 & NA & NA \\
\hline Terengganu & 1,291 & 1,385 & 1,306 & NA & NA \\
\hline Pulau Pinang & 1,590 & 1,707 & 1,959 & NA & NA \\
\hline Perak & 2,233 & 2,396 & 2,950 & NA & NA \\
\hline Selangor & 4,133 & 4,435 & 6,855 & NA & NA \\
\hline
\end{tabular}

Source: National Solid Waste Management Department and *SWCorp Malaysia

Landfilling is the least preferred method of managing waste but remain as the main method employed for waste disposal (Johari et al., 2014; Shahul Hamid \& Periathamby, 2012). Waste are disposed off at 157 operating disposal sites in the country but only 24 are sanitary landfills (SWCorp Malaysia, 2016). Non-sanitary landfills are controlled dump sites without appropriate system to contain the emissions (Shahul Hamid \& Periathamby, 2012). More than $40 \%$ of these landfills are reaching its design capacity and are due for closure within less than 5 years (Yahaya \& Larsen, 2008). The greenhouse gases emissions (GHG) from the waste sector recorded an upward trend from 223.1 million tonnes (Mt) of $\mathrm{CO}^{2}$ eq of GHG in 2000 to $292.9 \mathrm{Mt}$ $\mathrm{CO}^{2}$ eq in 2007(United Nations Malaysia, 2016). Malaysia is progressively phasing out unsanitary landfills and imposing strict measures to sanitary landfills. Other than landfilling, there are 4 small incinerators in Peninsular Malaysia with a total capacity of 180 tonnes of waste daily (SWCorp Malaysia, 2016). Acquiring land for new landfills are becoming difficult in the future.

The world trend on SWM has evolved from mere disposal towards sustainable waste management. The waste hierarchy concept of preventive, reuse, recycle, recovery and disposal has shifted to "close-the-loop" or "resource management" concept (Wilson, 2007). Recycling has been accepted globally as a sustainable option as it reduces disposal quantity and costs, turns wastes into resources, reduces the use of virgin materials, reduces health and environmental risks as well as extends the life span of landfills (Ma \& Hipel, 2016; Wilson, Rodic, \& Velis, 2013). Despite the development of technologies and adopted policies from developed countries, greater emphasis is put to promote waste separation behavior for recycling among individuals. Various researchers has repeatedly reported the poor participation of Malaysian household in performing recycling. The recycling rate recorded a mere amount of $5 \%$ in 2005, increasing to $15 \%$ in 2015 . This is low compared to the neighboring countries like Singapore $(61 \% ; 2003)$ and 
INTERNATIONAL JOURNAL OF ACADEMIC RESEARCH IN PROGRESSIVE EDUCATION AND DEVELOPMENT

Vol. 8, No. 4, 2019, E-ISSN: $2226-6348$ @ 2019 HRMARS

Thailand (22\%; 2009)(SWCorp Malaysia, 2012). The following paragraphs describes the timeline on the evolution of SWM policies in Malaysia to the current state.

\section{Evolution towards the National Solid Waste Management Policy 2006}

The development towards the realization of the National Solid Waste Management Policy 2006 has taken various phases. Reviews by scholars on SWM in Malaysia can be traced from late 1970s due to limited information and documentation (Hassan \& Rahman, 2000; Moh \& Abd. Manaf, 2017). SWM is a listed item under the concurrent list of the Federal Constitution of Malaysia where both state and the federal government have authority. In the earlier management of solid waste in Malaysia, Section 72 of the Local Government Act 1974 empowers the Local Authority (LA) to manage solid waste and public cleansing in areas under their jurisdiction. The Federal Government, through the Ministry of Housing and Local Government (MHLG), has been involved to provide financial resource for facilities, equipment, policies and awareness programs based on LA's applications (Jalil et al., 2015; Yahaya \& Larsen, 2008).

The municipal solid waste management during the 1970 s era was quite primitive. Household waste were collected to the LA assigned disposal sites (Periathamby, Hamid, \& Khidzir, 2009). The disposal sites were small open-dumping sites which were located near to residential areas. However, these sites were then considered sufficient to manage relatively small amount of waste estimated as $0.5 \mathrm{~kg}$ per person per day (Periathamby et al., 2009; Shahul Hamid \& Periathamby, 2012). The selection of the dumping sites were merely based on convenience rather than environmental considerations and health.

Faced with issues of increasing trend in MSW generation over the years and the need to standardize SWM system for the country, MHLG embarked on Action Plan for a Beautiful and Clean Malaysia (ABC Plan) in 1988, a plan that was neither endorsed nor implemented, earmarking the initial effort to introduce recycling program in Malaysia (Moh \& Manaf, 2014; Periathamby et al., 2009). Recycling campaigns were carried out from then on. The Eighth Malaysian Plan (8MP) charting the nation's development plan from 2001 to 2005 highlighted the adoption of a comprehensive waste management policy to address waste issues particularly on waste reduction, reuse and recycling (3Rs) (Government of Malaysia, 2000). The 9th Malaysian Plan (2006 - 2010) emphasizes the continuance of the 3Rs effort through extensive recycling awareness programs with collaboration with LA, private sectors and non-governmental organizations (NGOs). The National Strategic Plan for Solid Waste Management (NSP) adopted in 2005 outlined strategies towards sustainable waste management emphasizing on 3Rs, the use of appropriate technologies and public, private sectors and NGOs participation. Finally, the Master Plan on National Waste Minimization (MWM) 2006 was formulated aiming to strengthen institutional capacity and create a material cycle society to achieving a recycling target of 22 percent by 2020 (Government of Malaysia, 2006).

The Cabinet approved the National Solid Waste Management Policy 2006 (NSWMP 2006) on 13 September 2006 with the objective to enhance the national SWM that is comprehensive, integrated, cost effective, sustainable and acceptable by the community which reduces waste generation through 3Rs. The NSWMP 2006 consists of 6 objectives and 6 thrusts (Jabatan Pengurusan Sisa Pepejal Negara, 2016). In 2016, the NSWMP 2016 was announced to embrace the same principle as NSWMP 2006 with enhanced initiatives on method to increase 3R activities 
to include waste separation at source, pay-as-you-throw and deposit refund system. The NSWMP 2016 adds in 17 strategies and 50 action plans. The policy now includes the use of various policy instruments including information and awareness raising, regulation, institutional capacity, economic mechanism as well as infrastructure and services.

One of the key policy instruments enabling the implementation of other policy instruments is the regulation. The Solid Waste and Public Cleansing Management Act 2007 (Act 672) or SWMPC Act was passed by the Parliament in July 2007 and gazetted in August 2007. The Act 672 objectives are to regulate the management of solid waste to ensure standardized and high quality SWM services based on waste hierarchy concept(Johari et al., 2014; Moh \& Abd. Manaf, 2017; Periathamby et al., 2009). The Act is effective throughout Peninsular Malaysia, Federal Territory of Putrajaya and Labuan and implemented in phased. Currently, the Act is implemented in the states of Kedah, Perlis, Pahang, Negeri Sembilan, Melaka, Johor, the Federal Territories of Kuala Lumpur and Putrajaya. The Department of National Solid Waste Management, initially a division under the MHLG, was entrusted to formulate policies, strategies, action plans and to prepare regulations and agreements. The Solid Waste and Public Cleansing Management Corporation Act 2007 (Act 673) was passed in 2007 establishing Solid Waste Management and Public Cleansing Corporation (SWCorp) as the operational arm to manage the operational and implementation issues. The main implication of the Act is the federalization of the SWM from LAs.

The Act 672 has provided a guiding principle for the SWM sector as a whole. The waste separation at source was launched on 15 September 2015 and enforced effective 1 June 2016. Since its implementation, the recycling rate has gradually increased from $15 \%$ in 2015 to $21 \%$ in 2016 (Mentek, 2017). However, with ever increasing waste generation volume and envisioning higher recycling target requires refinement and improvements of current policy instruments. Highlighting the importance for policy maker needs to understand the behavioral outcome of the policy tools.

\section{The Behavioral Aspect of Policy Instruments}

Public policies are interventions made by the government to alter the governance or social behavior in achieving policy goals. The government exercises policy instruments in their plans and programs in their attempt to affect social change, thus accomplishing the desired policy goals. The complexity of analyzing policy instrument choices has drawn various scholars to develop taxonomies of policy tools with the intention to identify the sets of variables influencing the choice. Based on literature, the classification of policy instruments are subjective and varies according to the scholars as summarized in Table 2 . The selection of the policy instruments are based on each national government preference taking into consideration the state-society relations (Howlett, 1991). Therefore, the choice are "nation-bound" as different instruments are used at addressing the same problem (Howlett, 1991; Schneider \& Ingram, 1990). 
INTERNATIONAL JOURNAL OF ACADEMIC RESEARCH IN PROGRESSIVE EDUCATION AND DEVELOPMENT

Vol. 8, No. 4, 2019, E-ISSN: 2226-6348 @ 2019 HRMARS

Table 2: Taxonomies of Policy Instruments

\begin{tabular}{|l|l|}
\hline Author & Policy Instrument Categories \\
\hline Lowi (1972) & Distributive, redistributive, regulatory, constituent \\
\hline Hood (1984) & Nodality, authority, treasure, organisation \\
\hline Evert Vedung (1998) & Information, economic means, regulation \\
\hline $\begin{array}{l}\text { McDonnell and Elmore } \\
\text { (1986) }\end{array}$ & $\begin{array}{l}\text { Mandate, inducement, capacity-building, system- } \\
\text { changing }\end{array}$ \\
\hline Linder and Peters (1989) & continuum \\
\hline Doern and Phidd (1983) & continuum \\
\hline $\begin{array}{l}\text { Schneider and Ingram } \\
\text { (1990) }\end{array}$ & $\begin{array}{l}\text { authority, incentives, capacity-building, symbolic \& } \\
\text { hortatory, learning }\end{array}$ \\
\hline
\end{tabular}

Sources: (Bemelmans-Videc, Rist, \& Vedung, 2010; Elmore, 1987; Howlett, 1991; Linder

\& Peters, 1989; Schneider \& Ingram, 1990)

The behavioral dimensions of policy tools provides a comparative analysis on the relationship between policy tools and the target policy participants. Schneider and Ingram (1990) in their analysis on policy tools and the underlying behavioral assumptions highlighted that while policy makers are very clear on the policy characteristics and its effect, the outcome is dependent to target policy participation. Therefore, analysis on the behavioral dimension of policy tools is vital at formulating better strategies and plans to comprehend the reaction of the target population to the policy initiative. The paragraphs below deliberate the policy tools based on McDonell and Elmore (1986) categorization.

Authority tools are amongst the oldest method adopted by government to achieve policy goals. Authority tools refers to legitimate government authority preventing or requiring certain actions to be performed under specified circumstances (Schneider \& Ingram, 1990). Government uses the "stick" to prescribe the desired human behavior. In the context of NSWMP 2006, Part X of Act 672 requires household to separate their household waste at source accordingly while Part IV provide detail statements on enforcement provisions. The implementation of mandatory separation of waste at source requires the household to separate waste into 6 categories; residual waste, paper, plastic, other, garden waste and bulk waste. The residual waste comprising food waste and soiled waste will be collected twice a week while the recyclable waste will be collected once a week, referring this to the " $2+1$ " collection system.

Inducement or "carrot" refers to the offering of payoffs or resources as the push factor to produce the desired behavior. Individuals are utility maximizers whom in the absence of additional resources will not respond positively to take the policy-relevant action. In the context of Malaysia, the recycling centers and buy back centers operated by private companies and nongovernmental organizations (NGOs) provides the economic incentives for residents. The recycling centers and buy back centers are mostly positioned in highly populated middle-high income areas (Safitri Zen, Zainon Noor, \& Yusuf, 2014). In the future, "take-back-system" and "deposit-refund-system" may be few feasible options as highlighted by Clause 102 in Act 672.

Capacity-building involves investment made on materials and human resources in meeting long term developmental objectives. The capacity-building tool may include information, knowledge transfer, communication, training, facilities, education, moral suasion 
and resources to enable individuals to achieve the intended policy results. Information does not mandate the target group to behave in a certain manner but only reasoning and moral suasion. Information can also act as meta-policy instrument to spread the information about other policy instruments. The SWCorp Strategic Plan 2014-2020 has highlighted its core strategies, among others include 'Communicate, Educate, Engage, Empower, and Enforce' (C4E) in their attempt to increase public awareness through campaigns and publicity programs (Moh \& Abd. Manaf, 2017; SWCorp Malaysia, 2012).

System-changing as the policy tools refers to the new arrangements in the transfer of authority of delivering the public goods and services (Elmore, 1987). The bottom-up approach involves deliberative processes to involve broad stakeholders. While the process aggregate the valuable opinion from the public, it also create transparency in the decision making process, in turn improves public satisfaction and support for the policy. In Malaysia, public hearings, meetings and consultations are the common methods for public participation(Suzie et al., 2015).

An effective policy measure increases the desirability for the target population to perform the target behavior (Steg \& Vlek, 2009). Each policy instrument plays different role. Regulation would implicate compliance, economic incentives provides the "carrot", capacity-building and information increases awareness while system-changing refers to the collaborative bottom-up approach to gain public support to perform the desired behavior. When the implemented policy instruments are perceived as effective, the higher is the motivation of the target population to perform the behavior. Perceived policy effectiveness is an important aspect to be studied to assess the relationship of the implemented policies in explaining recycling behavioral.

\section{Theory of Planned Behavior}

Recycling is an activity that requires considerable effort from the individual has to distinguish the recyclable items, cleaning them before collection, store them in the right categories for collection or to drop-off collection centre (Boldero, 1995; Varotto \& Spagnolli, 2017). Participating in waste separation program requires individual significant amount of time, storage area, money and effort. Consequently, the household decision to participate in a recycling activity is complex as it is influenced by a number of factors. Although recycling is part of pro-environmental behavior, due to its uniqueness, it has different antecedents from proenvironmental behaviors (Tonglet, Phillips, \& Read, 2004). It is also the most studied environmentally responsible behavior (Boldero, 1995; Lizin, Dael, \& Passel, 2017).

The Theory of Planned Behavior (TPB), as proposed by Ajzen (1991), provides a theoretical framework to systematically identify the socio-psychological determinants of recycling behavior (Ajzen, 1991; M. Chen \& Tung, 2010; Tonglet et al., 2004). Based on the theory, the individual behavior is dependent of the person intention which in turn is being influenced by three other independent variables. Attitude reflects the positive or negative evaluation of performing the behavior, subjective norm reflect the perceived social pressure in engaging to the behavior and perceived behavior control refers to individual evaluation on the individual ability of performing the behavior (Graham-rowe, Jessop, \& Sparks, 2015; Oztekin, Teksöz, Pamuk, Sahin, \& Sultan, 2017). The individual intention to perform a particular behavior is not only influenced by the person attitude about the behavior but also affected by the social pressure and 
the perceived ease of performing it. The TPB assumes the existence of conscious reasoning in the formation of the intention to perform a behavior (M. Chen \& Tung, 2010).

The intention to undertake various types of behavior has been empirically tested by scholars with considerable success, particularly on sustainable and pro-environment lifestyle. The theory has been applied by many scholars to explain different behaviors related to physical activities (Úbeda-colomer, Martin, Monforte, Perez-Samaniego, \& Devís-Devís, 2019), environmental travel (Liu, Snow, \& Che, 2019), energy saving (Fan, Xu, \& Nie, 2019; Wang, Zhang, Yin, \& Zhang, 2011), moral obligation(M. F. Chen, 2016; Zhang, Huang, Yin, \& Gong, 2015), food wastage (Goh \& Jie, 2019; Werf, Seabrook, \& Gilliland, 2019) and low carbon society (Kaffashi \& Nasir, 2019). The theory has also been successfully used to examine the factors influencing behavior in the field of waste management (Lizin et al., 2017; Tonglet et al., 2004; Wan, Qiping, \& Choi, 2017; Wan, Shen, \& Yu, 2014b).

Researchers has suggested that successful recycling programs requires a comprehensive understanding of the household attitude towards recycling and their perception on the barriers in undertaking recycling (M. Chen \& Tung, 2010; Knussen, Yule, Mackenzie, \& Wells, 2004). Among the early research on waste recycling includes (Boldero, 1995) on newspaper recycling and (Taylor \& Todd, 1995) on integrated model on household waste recycling and composting behavior. While researchers has confirmed the predictive validity of the TPB (Valle, Reis, Menezes, \& Rebelo, 2004; Tonglet et al., 2004), its adequacy to explain recycling behavior has been debated (Boldero, 1995; Tonglet et al., 2004). The TPB is a flexible model as it allows the inclusion of additional variables provided that the variables contribute to the explanation of the behavior (Ajzen, 1991; Tonglet et al., 2004; Wan et al., 2017). Among the additional variables incorporated were moral norm, past experience, situational factors and consequences of recycling (Tonglet et al., 2004); past behavior, perceived habit, and perceived lack of facilities (Knussen et al., 2004); environmental awareness (Ramayah, Lee, \& Lim, 2012) and perceived policy effectiveness (Wan et al., 2014b).

Wan and Shen (2013) discussed the significance of incorporating perceived policy effectiveness (PPE) in understanding the factors that influences recycling behavior. The PPE is defined as "individual's favorable or unfavorable evaluation on a specific policy measure" (Wan et al., 2014b, p. 144). A policy measure functions as a stimulation means, thus a positive perception on policy effectiveness will provide a positive relationship to perform certain behavior (Wan, Shen, \& Yu, 2014a). Scholars have incorporated PPE variable in the research to better understand the recycling behavior (Liao, Zhao, Zhang, \& Chen, 2018; Wan et al., 2014b, 2014a; $\mathrm{Xu}$, Ling, Lu, \& Shen, 2017). The PPE has proven to have significant relationship to understand recycling behavior (Liao et al., 2018; Wan et al., 2014b; Xu et al., 2017). As each government policy instruments provides a different type of stimulus to individuals, study to investigate the relationships of each policy tools at influencing individual recycling behavior is an important area to be researched. Figure 1 provides the conceptual framework. 


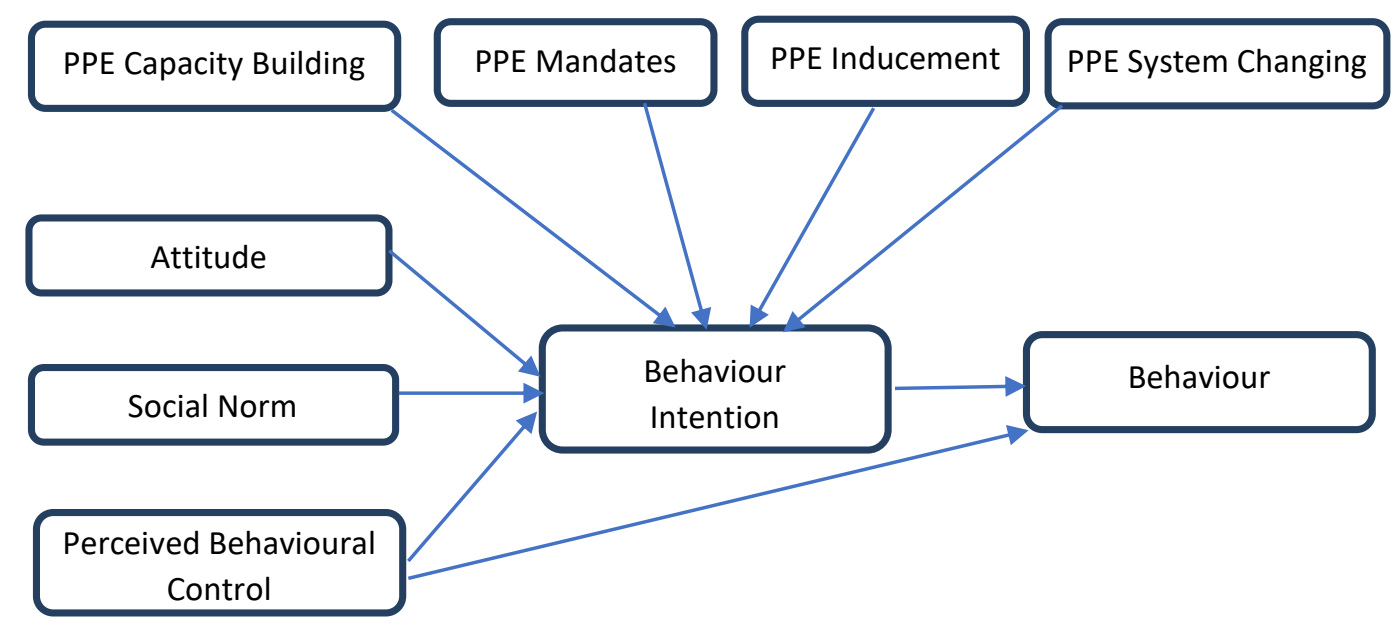

Figure 1: The Conceptual Framework

\section{Conclusions}

The main challenge facing Malaysia is to effectively and sustainably manage the continuous increasing of MSW. Globally, the SWM is progressively transforming from the primitive type of landfilling to managing waste based on the waste hierarchy. The most critical challenge in managing waste efficiently is inculcating the community to practice the cleanliness culture and actively perform waste separation at source. The target population behavior is a significant factor to be considered in order to achieve higher level of recycling rate. The success of SWM is beyond technological scope but is heavily dependent on public participation in performing the desired behavior. Government policy tools can act as a motivational factor to the desired behavior that understanding the behavioral aspect of the policy instruments will provide the policymaker indication to further enhance its strategies.

The TPB variables lays the foundation to explain recycling intention and behavior. This paper provides the conceptual framework to analyse the relationship of each policy tools to recycling intention. The additional variables, PPE Capacity Building, PPE Mandates, PPE Inducement and PPE System Changing, are expected to increase the predictive power of TPB. It is hypothesized that the positive perception on implemented policies will have positive relationship to recycling behavior. The results will be informational for the government to strategies their policy to encourage recycling. This will also enable the government to allocate their resources in accordance to the specific target group needs. Practical solutions are "nationbound". The passage for a modernized solid waste management system should "identify simple, appropriate and affordable solutions that can be implemented progressively, giving the inhabitants the best system they can afford and laying the basis for future improvements" (Wilson \& Scheinberg, 2010, p. 1056). 
INTERNATIONAL JOURNAL OF ACADEMIC RESEARCH IN PROGRESSIVE EDUCATION AND DEVELOPMENT

Vol. 8, No. 4, 2019, E-ISSN: 2226-6348 ㄷ 2019 HRMARS

\section{References}

\section{Journal}

Ajzen, I. (1991). The theory of planned behavior. Organizational Behavior and Human Process, 50, 179-211. https://doi.org/https://doi.org/10.1016/0749-5978(91)90020-T

Boldero, J. (1995). The prediction of household recycling of newspapers: The role of attitudes, intentions, and situational factors. Journal of Applied Social Psycology, 25(5), 440-462.

Chen, M. F. (2016). Extending the theory of planned behavior model to explain people's energy savings and carbon reduction behavioral intentions to mitigate climate change in Taiwanmoral obligation matters. Journal of Cleaner Production, 112, 1746-1753. https://doi.org/10.1016/j.jclepro.2015.07.043

Chen, M., \& Tung, P. (2010). The moderating effect of perceived lack of facilities on consumers ' recycling intentions. Environment and Behavior, 42(6), $824-844$. https://doi.org/10.1177/0013916509352833

Elmore, R. F. (1987). Instruments and strategy in public policy. Policies Studies Review, 7(1), 174-186.

Fan, Y., Xu, J., \& Nie, H. (2019). Exploring reasons behind careful-use, energy-saving behaviors in residential sector based on the theory of planned behavior : Evidence from Changchun, China, 230. https://doi.org/10.1016/j.jclepro.2019.05.101

Goh, E., \& Jie, F. (2019). To waste or not to waste : Exploring motivational factors of generation $Z$ hospitality employees towards food wastage in the hospitality industry. International Journal of Hospitality Management, 80(January), 126-135. https://doi.org/10.1016/j.ijhm.2019.02.005

Graham-rowe, E., Jessop, D. C., \& Sparks, P. (2015). Predicting household food waste reduction using an extended theory of planned behavior. "Resources, Conservation \& Recycling," 101, 194-202. https://doi.org/10.1016/j.resconrec.2015.05.020

Hassan, M. N., \& Rahman, R. A. (2000). Recycling in Malaysia : problems and prospects. Waste Management \& Research, 18, 320-328.

Howlett, M. (1991). Policy Instruments, policy styles, and policy implementation : national approaches to theories of instrument choice. Policies Studies Jornal, 19(2).

Jalil, N. A. A., Basri, H., Basri, N. E. A., \& Abushammala, M. F. M. (2015). The Potential of biodrying as pre-treatment for municipal solid waste in Malaysia Journal of Advanced Review on Scientific Research, 7(1), 1-13.

Johari, A., Alkali, H., Hashim, H., Ahmed, S. I., \& Mat, R. (2014). Municipal Solid Waste Management and Potential Revenue from Recycling in Malaysia. Modern Applied Science, 8(4). https://doi.org/10.5539/mas.v8n4p37

Kaffashi, S., \& Nasir, M. (2019). Transforming to a low carbon society : An extended theory of planned behavior of Malaysian citizens. Journal of Cleaner Production, 235, 1255-1264. https://doi.org/10.1016/j.jclepro.2019.07.047

Knussen, C., Yule, F., Mackenzie, J., \& Wells, M. (2004). An analysis of intentions to recycle household waste : The roles of past behavior, perceived habit, and perceived lack of facilities. Journal of Environmental Psychology, 24, 237-246.

https://doi.org/10.1016/j.jenvp.2003.12.001

Liao, C., Zhao, D., Zhang, S., \& Chen, L. (2018). Determinants and the moderating effect of 
INTERNATIONAL JOURNAL OF ACADEMIC RESEARCH IN PROGRESSIVE EDUCATION AND DEVELOPMENT

Vol. 8, No. 4, 2019, E-ISSN: 2226-6348 @ 2019 HRMARS

perceived policy effectiveness on residents' separation intention for rural household solid waste. International Journal of Environmental Research and Public Health, 15(4), 1-17. https://doi.org/10.3390/ijerph15040726

Linder, S. H., \& Peters, B. G. (1989). Instruments of government : Perceptions and contexts. Journal of Public Policy, 9(1), 35-58. Retrieved from https://ojs.unbc.ca/index.php/design/article/viewFile/1482/1224

Liu, J., Snow, J., \& Che, T. (2019). Understanding perceived environment quality in affecting tourists ' environmentally responsible behaviors : A broken windows theory perspective. Tourism Management Perspectives, 31(41471467), 236-244. https://doi.org/10.1016/j.tmp.2019.05.007

Lizin, S., Dael, M. V., \& Passel, S. V. (2017). Battery pack recycling : Behavior change interventions derived from an integrative theory of planned behavior study. Resources, Conservation \& Recycling, 122, 66-82. https://doi.org/10.1016/j.resconrec.2017.02.003

Ma, J., \& Hipel, K. W. (2016). Exploring social dimensions of municipal solid waste management around the globe - A systematic literature review. Waste Management, 56, 3-12. https://doi.org/10.1016/j.wasman.2016.06.041

Moh, Y. C., \& Manaf, L. A. (2017). Solid waste management transformation and future challenges of source separation and recycling practice in Malaysia. "Resources, Conservation \& Recycling," 116, 1-14. https://doi.org/10.1016/j.resconrec.2016.09.012

Moh, Y. C., \& Manaf, L. A. (2014). Overview of household solid waste recycling policy status and challenges in Malaysia. Resources, Conservation \& Recycling, 82, 50-61. https://doi.org/10.1016/j.resconrec.2013.11.004

Nurudin, M. S., Hashim, R., Rahman, S., Zulkifli, N., Mohamed, A. S. P., \& Hamik, S. A. (2015). Public participation process at local government administration: A case study of the Seremban Municipal Council, Malaysia. Procedia - Social and Behavioral Sciences, 211, 505-512. https://doi.org/10.1016/j.sbspro.2015.11.067

Valle, O. D. P., Reis, E., Menezes, J., \& Rebelo, E. (2004). Behavioral determinants of household recycling participation: The Portuguese case. Environment and Behavior, 36(4), 505-540. https://doi.org/10.1177/0013916503260892

Oztekin, C., Teksöz, G., Pamuk, S., Sahin, E., \& Sultan, D. (2017). Gender perspective on the factors predicting recycling behavior : Implications from the theory of planned behavior. Waste Management, 62, 290-302. https://doi.org/10.1016/j.wasman.2016.12.036

Periathamby, A., Hamid, F. S., \& Khidzir, K. (2009). Evolution of solid waste management in Malaysia: impacts and implications of the Solid Waste Bill, 2007. Journal of Material Cycles and Waste Management, 11(2), 96-103. https://doi.org/10.1007/s10163-008-0231-3

Ramayah, T., Lee, J. W. C., \& Lim, S. (2012). Sustaining the environment through recycling: An empirical study. Journal of Environmental Management, 102, 141-147. https://doi.org/http://dx.doi.org/10.1016/j.jenvman.2012.02.025

Schneider, A., \& Ingram, H. (1990). Behavioral assumptions of policy tools. The Journal of Politics, 52(2), 510-529.

Hamid, S. F., \& Periathamby, A. (2012). Trends in sustainable landfilling in Malaysia, a developing country. Waste Management \& Research, 30(7), 656-663. https://doi.org/10.1177/0734242X12437564 
INTERNATIONAL JOURNAL OF ACADEMIC RESEARCH IN PROGRESSIVE EDUCATION AND DEVELOPMENT

Vol. 8, No. 4, 2019, E-ISSN: 2226-6348 @ 2019 HRMARS

Steg, L., \& Vlek, C. (2009). Encouraging pro-environmental behavior : An integrative review and research agenda. Journal of Environmental Psychology, 29(3), 309-317. https://doi.org/10.1016/j.jenvp.2008.10.004

Taylor, S., \& Todd, P. (1995). An integrated model of waste management behavior: A test of household recycling and composting intentions. Environment and Behavior, 27(5), 603630.

Tonglet, M., Phillips, P. S., \& Read, A. D. (2004). Using the theory of planned behavior to investigate the determinants of recycling behavior: A case study from Brixworth, UK. Resources, Conservation \& Recycling, 41, 191-214. https://doi.org/10.1016/j.resconrec.2003.11.001

Úbeda-colomer, J., Martin, K. A., Monforte, J., Perez-Samaniego, V., \& Devís-Devís, J.. (2019). Predicting physical activity in university students with disabilities : The role of social ecological barriers in the theory of planned behavior. Disability and Health Journal, 12, 574-580. https://doi.org/10.1016/j.dhjo.2019.06.008

Varotto, A., \& Spagnolli, A. (2017). Psychological srategies to promote household recycling . A systematic review with meta-analysis of validated field interventions. Journal of Environmental Psychology, 51, 168-188. https://doi.org/10.1016/j.jenvp.2017.03.011

Wan, C., Qiping, G., \& Choi, S. (2017). Experiential and instrumental attitudes : Interaction effect of attitude and subjective norm on recycling intention. Journal of Environmental Psychology, 50, 69-79. https://doi.org/10.1016/j.jenvp.2017.02.006

Wan, C., Shen, G. Q., \& Yu, A. (2014a). The moderating effect of perceived policy effectiveness on recycling intention. Journal of Environmental Psychology, 37, 55-60. https://doi.org/10.1016/j.jenvp.2013.11.006

Wan, C., Shen, G. Q., \& Yu, A. (2014b). The role of perceived effectiveness of policy measures in predicting recycling behavior in Hong Kong. "Resources, Conservation \& Recycling," 83, 141-151. https://doi.org/10.1016/j.resconrec.2013.12.009

Wang, Z., Zhang, B., Yin, J., \& Zhang, Y. (2011). Determinants and policy implications for household electricity-saving behavior: Evidence from Beijing, China. Energy Policy, 39(6), 3550-3557. https://doi.org/10.1016/j.enpol.2011.03.055

Werf, P. V. D., Seabrook, J. A., \& Gilliland, J. A. (2019). Food for naught : Using the theory of planned behavior to better understand household food wasting behavior. The Canadian Geographer, 63(3), 1-16. https://doi.org/10.1111/cag.12519

Wilson, D. C. (2007). Development drivers for waste management. Waste Management \& Research, 25, 198-207. https://doi.org/10.1177/0734242X07079149

Wilson, D. C., Rodic, L., \& Velis, C. A. (2013). Integrated sustainable waste management in developing countries. In Proceedings of the Institution of Civil Engineers Waste (pp. 52-68). ICE Publishing. Retrieved from http://dx.doi.org/10.1680/warm.12.00005

Wilson, D. C., \& Scheinberg, A. (2010). What is good practice in solid waste management? Waste Management \& Research, 28(12), 1055-1056. https://doi.org/10.1177/0734242X10392106

Xu, L., Ling, M., Lu, Y., \& Shen, M. (2017). Understanding household waste separation behavior: Testing the roles of moral, past experience and perceived policy effectiveness within the theory of planned behavior. Sustainability, 9(4), 625. https://doi.org/10.3390/su9040625 
INTERNATIONAL JOURNAL OF ACADEMIC RESEARCH IN PROGRESSIVE EDUCATION AND DEVELOPMENT

Vol. 8, No. 4, 2019, E-ISSN: 2226-6348 @ 2019 HRMARS

Zen, I. S., Zainon N. Z., \& Yusuf, R. O. (2014). The profiles of household solid waste recyclers and non-recyclers in Kuala Lumpur, Malaysia. Habitat International, 42, 83-89. https://doi.org/10.1016/j.habitatint.2013.10.010

Zhang, D., Huang, G., Yin, X., \& Gong, Q. (2015). Residents ' waste separation behaviors at the source : Using SEM with the theory of planned behavior in Guangzhou, China. Int. J. Environ. Res. Public Health, 9475-9491. https://doi.org/10.3390/ijerph120809475

\section{Book}

Bemelmans-Videc, M., Rist, R. C., \& Vedung, E. (Eds.). (2010). Carrots, Sticks \& Sermons (5th ed.). New Brunswick (U.S.A.) and London (U.K.): Transaction Publishers.

Government of Malaysia. (2000). 8th Malaysia Plan 2000-2005. Percetakan Nasional Berhad. Government of Malaysia. (2006). 9th Malaysia Plan 2006-2010. Percetakan Nasional Berhad. Jabatan Pengurusan Sisa Pepejal Negara. (2016). Dasar Pengurusan Sisa Pepejal Negara 2016. Retrieved from www.jpspn.kpkt.gov.my

Ministry of Housing and Local Government. (2010). Perangkaan Terpilih KPKT 2010. Retrieved from www.kpkt.gov.my/index.php/pages/view/597?mid=113

Ministry of Housing and Local Government. (2012). Perangkaan Terpilih KPKT 2012. Retrieved from www.kpkt.gov.my/index.php/pages/view/597?mid=113

Ministry of Housing and Local Government. (2014). Perangkaan Terpilih KPKT 2014. Retrieved from www.kpkt.gov.my/index.php/pages/view/597? mid=113

SWCorp Malaysia. (2014). Pelan Strategik SWCorp 2014-2020 : Melakar Dimensi Baharu Menuju Masa Depan. Retrieved from http://www.swcorp.gov.my

SWCorp Malaysia. (2016). Kompendium Pengurusan Sisa Pepejal Malaysia 2016 (1st ed.). Solid Waste Corporation Malaysia.

SWCorp Malaysia. (2019). Kompendium Pengurusan Sisa Pepejal Malaysia 2019. Solid Waste Corporation Malaysia.

The World Bank. (1999). What a Waste : Solid Waste Management in Asia. Retrieved from http://documents.worldbank.org/curated/en/694561468770664233/What-a-waste-solidwaste-management-in-Asia

The World Bank. (2012). What a Waste: A Global Review of Solid Waste Management. Retrieved from https://openknowledge.worldbank.org/handle/10986/17388

United Nations Malaysia. (2016). Malaysia Millenium Development Goal Report 2015. United Nations Malaysia. Retrieved from http://un.org.my/upload/undp_mdg_report_2015.pdf

\section{Others}

Government of Malaysia. Solid Waste and Public Cleansing Management Act (2007). Malaysia.

Mentek, M. (2017). Solid Waste Management in Malaysia : Towards A Holistic Approach. In International Solid Waste Association (ISWA) World Congress. Ministry of Urban Wellbeing,Housing and Local Government. Retrieved from http://www.swcorp.gov.my/docfile/kertas-taklimat/Towards a Holistic Approach.pdf

Rohana, S. I. (2017). Kitar semula kurangkan kos pelupusan sisa pepejal. Berita Harian. Retrieved from https://www.bharian.com.my/berita/wilayah/2017/11/354377/kitarsemula-kurangkan-kos-pelupusan-sisa-pepejal 


\section{INTERNATIONAL JOURNAL OF ACADEMIC RESEARCH IN PROGRESSIVE EDUCATION AND}

DEVELOPMENT

Vol. 8, No. 4, 2019, E-ISSN: 2226-6348 @ 2019 HRMARS

Yahaya, N., \& Larsen, I. (2008). Federalising Solid Waste Management In Peninsular Malaysia. In Proceeding of International Solid Waste Association (ISWA) World Congress, Singapore. 